\title{
Unusually large clastic dykes formed by elutriation of a poorly sorted, coarser-grained source
}

\author{
Pierre-Simon Ross* \& James D.L. White \\ Department of Geology, University of Otago, PO Box 56, Dunedin, New Zealand \\ * Corresponding author
}

\begin{abstract}
Tuff-dykes of unusual size invade coarser-grained volcaniclastic rocks of the Jurassic Mawson Formation at Coombs Hills and Allan Hills, Antarctica. We infer that the material for the largest dykes was elutriated from their host's matrix. To our knowledge, this mode of genesis has not been invoked before. In this volcanic setting elutriation was driven by magmatic heat, but the production of relatively finer-grained clastic dykes by elutriation of material from coarser ill-sorted sources may be significant in many settings.
\end{abstract}

Keywords: clastic dykes, elutriation, volcaniclastic rocks, fluidisation

Introduction. Large tuff-filled clastic dykes invade volcaniclastic deposits associated with the Ferrar large igneous province. These dykes are of interest because of their setting, scale (up to $75 \mathrm{~m}$ wide), composition, and distinctive origin. They are challenging to interpret because, unlike many clastic dykes in sedimentary sequences, no source horizon is known that matches the composition and grain size of debris in the dykes. This appears to require either (a) that there is a hidden source having the required compositional and granulometric characteristics, or (b) that the debris be newly formed simultaneous with dyke injection, or (c) that it be extracted from coarser-grained deposits in which the matrix material matches the dykes' grain size. Below we document the characteristics of the dykes and address each of these possibilities.

Geological context. Clastic dykes cut through coarse, poorly sorted volcaniclastic deposits of the Jurassic Mawson Formation at Coombs Hills and southern Allan Hills in South Victoria Land, Antarctica (Gunn and Warren 1962; Ballance and Watters 1971; Bradshaw 1987; Fig. 1). The Mawson Formation and correlatives constitute the sub-flood basalt, volcaniclastic part of the Ferrar large igneous province (Elliot 2000). The Ferrar province also includes large mafic dykes and sills referred to as the Ferrar Dolerite (Fleming et al. 1997).

The Mawson Formation at Coombs Hills is predominantly the coarse-grained, non-bedded, poorly sorted infill of a phreatomagmatic vent complex (White and McClintock 2001). Southern Allan Hills outcrops are dominated by meters-thick beds of lapilli-tuff and tuffbreccia that cover both thinly bedded volcaniclastic deposits and chaotic deposits (authors' unpublished data;
Fig. 1). In both areas, fragments in the Mawson consist principally of formerly glassy basaltic clasts, plus rock fragments and quartz particle derived from Beacon Supergroup sedimentary rocks. The lower part of the Mawson Formation in central Allan Hills is quite different, and will be described elsewhere; no clastic dykes of the types described below were seen there. In the Coombs Hills vent complex, rare tabular megablocks ("rafts") of bedded volcaniclastic material "float" in non-bedded, poorly sorted lapilli-tuffs. The rafts, interpreted as slumped equivalents of surface volcaniclastic deposits, may be genetically linked with some of the clastic dykes.

Description of clastic dykes in the Mawson Formation. Two types of clastic dykes exist at Coombs Hills and southern Allan Hills. The largest and most common dykes (type 1) consist of pale brown to beige, coarse to fine tuff (Fig. 2). These dykes have length:width ratios $>>10: 1$, pinch and swell, and can change direction abruptly. The dykes wider than $5 \mathrm{~m}$ at Coombs Hills are all of this type, and generally have a massive interior with $20-200 \mathrm{~cm}$ thick, wall-parallel laminated margins on each side. Narrower type 1 dykes can be massive or laminated throughout their width.

The second, much less abundant, type of clastic dyke ("type 2") is only present at Coombs Hills, and consists of juxtaposed bands of different volcaniclastic material. These bands are similar to the beds in volcaniclastic rafts and some of the in situ bedded sequences overlying the vent complex. The bands include lapilli-tuffs, coarse tuffs, and fine tuffs of variable composition and internal structure (laminated vs. internally massive). Type 2 dykes generally are shorter than type 1 dykes for a given width, are never wider than $5 \mathrm{~m}$, and 
show gradational relationships from banded central parts into non-banded tips that bend and bifurcate. These dykes are interpreted as partially remoulded volcaniclastic rafts (White and McClintock 2001), and their origin will not be discussed further here.

The majority of the measured dykes, and all those wider than $2 \mathrm{~m}$, are found at Coombs Hills (Fig. 3). At southern Allan Hills only 13 dykes were found, the widest measuring $1.5 \mathrm{~m}$ across. In both areas, the distributions of widths are approximately log-normal, with many narrow dykes and only a few large ones (some narrow dykes were not measured at Coombs Hills). The widest dyke at Coombs Hills $(75 \mathrm{~m})$ can be followed over nearly $1.5 \mathrm{~km}$; its large size is apparent by comparison with Boehm and Moore's (2002) description of $\leq 150$ m-wide Miocene dykes in California as "the largest subaerial exposures of clastic intrusions on earth".

The clastic material filling type 1 dykes comprises $60-90 \%$ ash-grade particles no larger than $0.5 \mathrm{~mm}$, in a matrix of altered mud-grade basaltic ash and clays with a cement of zeolites and minor calcite. The petrographically resolvable ash includes $15-45 \%$ angular to sub-rounded detrital quartz particles $(<1 \mathrm{~mm}), 20-55 \%$ dense to incipiently vesicular blocky basaltic fragments (vesicularity index of Houghton and Wilson 1989), 0-5\% poorly to moderately vesicular basaltic fragments, and 15\% Beacon clasts (mostly siltstone, mudstone and coal). This clast assemblage is essentially the same as that of the ash fraction of the coarser facies in Mawson Formation (lapilli-tuffs and tuff-breccias). The particle size distribution of a structureless tuff sample from the interior of the widest clastic dyke is shown on figure 4 . The size distribution of the finer than $1.5 \phi$ fraction of a typical Mawson lapilli-tuff is also shown for comparison.

In addition to volcaniclastic deposits of the Mawson Formation, the dykes also cut some basaltic stocks tens of meters wide; this indicates that the dykes were emplaced quite late in the overall sequence of events at Coombs Hills because the stocks cut every other lithofacies. Only some basalt dykes cut the clastic dykes. All clastic dyke dips are steep to vertical, with most vertical.

Models of clastic dyke formation that do not work for the Mawson Formation. A classic model of sand dyke formation is by sudden liquefaction, requiring (i) a suitable body of water-saturated sand; (ii) a trigger for liquefaction (e.g., earthquakes or sudden loading, see Jolly and Lonergan 2002 for a review); and (iii) an open or opening fracture for the mobilised material to flow into, in response to a pressure gradient. For type 1 clastic dykes in the Mawson Formation, both the host, which is unusually coarse (lapilli-tuffs and tuff-breccias), and the source of the material, which does not match any extensive source beds known in the area or inferred to lie beneath the emplacement sites, are problems.

The basalt dykes, which cross-cut clastic dykes, often have peperitic margins where intruding the vent- complex fill at Coombs Hills. This means that the lapillituffs and tuff-breccias were wet and at least locally poorly consolidated during clastic dyke emplacement. Such material is not readily fractured (although a fine ash fraction, now petrographically irresolvable, might have rendered it somewhat cohesive), but clastic dykes were nevertheless emplaced. High propagation rates are inferred to have allowed the dykes to advance through both incompletely lithified Mawson debris, and the stocks discussed previously.

A hidden source of material? Could a thick bed of tuff have been available and partly mobilised and injected to form type 1 clastic dykes? The Coombs Hills volcaniclastic complex is excavated into the pre-volcanic stratigraphy (White and McClintock 2001). Development of a coarse-fragment-free, subaerially deposited, unit at the base of the vent complex infill seems implausible, because it would require an open crater hundreds of meters deep and over $5 \mathrm{~km}$ wide.

The occurrence of a large volcaniclastic raft "floating" in a type 1 clastic dyke provides support for a genetic relationship between type 1 dykes and volcaniclastic rafts. These rafts were originally surface phreatomagmatic deposits, which were probably wet when they slumped into the vent complex. However, whether enough (and large enough) volcaniclastic rafts existed to supply material for all the clastic dykes is doubtful, if the present levels of exposure in the Mawson at Coombs Hills also reflect the raft density at depth. No volcaniclastic rafts were seen in southern Allan Hills. A further problem is that although Beacon rafts are at least three times more abundant at Coombs Hills than volcaniclastic rafts, no significant sandstone dykes are observed there. Because they were 'soft' when they slumped down the vents, these Beacon rafts should also have produced large clastic dykes if the remoulding/remobilisation of rafts was the dominant mechanism.

Could the debris be newly formed? To form the clastic dyke debris at the time of dyke injection, large amounts of magma and country rock need to be fragmented and mobilised in the subsurface. This is essentially the model discussed by Grapes et al. (1974) for the clastic dykes and sills associated with dolerite sills in the Beacon sequence at Allan Hills. Small tuff dykes formed by phreatomagmatic processes are known elsewhere (Heiken et al. 1998), but both the scale and, again, the relatively narrow grain size range of the dykes at Coombs Hills (Fig. 4), are a problem. The common host for the Coombs Hills dykes is very poorly sorted, contains clasts up to several meters across, and has a median grain size $>2 \mathrm{~mm}$ (authors' unpublished data). We regard synintrusion fragmentation of a basaltic intrusion as an implausible means of generating clastic dykes having the componentry and narrow grain size range observed.

A new model for the formation of intrusion-related clastic dykes. A scavenging, or sorting, model involves fluidisation of poorly sorted Mawson Formation lapillituffs, perhaps with a contribution from volcaniclastic rafts, 
with the fine particles elutriated then injected to form clastic dykes. Well sorted materials can be homogeneously fluidised (all particles supported by the upward-streaming fluid) given a sufficient fluid velocity. However, for poorly sorted (sorting >1) materials such as the Mawson debris, complete particulate fluidisation by water or volcanic gas is not possible and only aggregative fluidisation or wholesale entrainment can occur (Wilson 1980; Roche et al. 2001). Elutriation pipes are present in tuff layers at Allan Hills, and irregularly shaped cement-rich zones are also present in lapilli-tuffs and tuff-breccias at both Coombs Hills and Allan Hills. This indicates that parts of the Mawson debris have been fluidised and fine material suitable for type 1 clastic dykes - elutriated. Magmatic heat from large basaltic intrusions, exposed in abundance at the margins of the Coombs Hills vent complex (Fig. 1) and in north-eastern Allan Hills, is likely to have driven the fluids (some of these intrusions cut Mawson deposits, and basaltic dykes cut the clastic dykes, so the timing of the magmatic intrusions is appropriate).

We infer that the framework through which transport took place consists of lapilli lodged within elutriation networks similar to those observed in the field (vertical "pipes" having elongated sheet-like forms in three dimensions). The variably coarse lapilli infill of the elutriation pipes is inferred to have formed when coarser fragments in upward-moving slurries became jammed against one another where slurry flow was impeded at bends and constrictions in the irregular network pathways. The slurries had, initially, formed by wholesale entrainment of debris by vaporisation of pore water at intrusion contacts (Fig. 5). This two-stage process allowed initial mobilisation of poorly sorted material and opening of elutriation pathways followed by sorting, or filtering, of material through the same pathways as they became partly occluded by deposition (locking in) of coarser fragments.

The great width and extent of some dykes is an issue with this elutriation model. Injection of such large volumes of ash could be accomplished in stages, but away from the outer few decimetres of the dykes, there are no internal contacts to provide evidence for such multiple injection. The other alternative, formation by a single injection, requires that large volumes of ash be mobilised over very short timescales, and it is difficult to reconcile this rapidity with the need to sort or filter the ash from a poorly sorted source. A possible solution to this rate issue would be if dyke formation were a two-stage process, consisting of (1) relatively slow segregation of the proper material from the host and accumulation into some form of temporary reservoir, and (2) rapid injection into a fracture (Fig. 5). To the extent that the dykes may have grown by repeated injections, the need for such pre-injection accumulation is lessened.

Conclusions. Clastic dykes in the Mawson Formation at Coombs Hills formed late in the history of the volcaniclastic complex and are amongst the largest exposed clastic intrusions on earth. The host lapilli-tuffs and tuff-breccias were neither strongly cohesive nor lithified at the time of emplacement; high emplacement rates were required to open brittle fractures in this material and in existing basaltic stocks. No appropriate source horizon for the clastic dyke material is either known or likely to exist at depth, and we infer that the material for the type 1 dykes at Coombs Hills was obtained by mobilization and sorting/filtering of the coarse vent-filling debris by fluidisation above large basaltic intrusions. Such production of relatively finer-grained clastic dykes by elutriation of material from coarser ill-sorted sources may be significant elsewhere, particularly where potential sources include gravel-bearing sands, because the same sort of transport-lodgement and separation of fine particles from coarser ones in a rising fluid are likely. In this context, note that competence-controlled settling/deposition of large clasts may take place from "liquified" flows in a manner analogous with boulder deposition from granular mass flows (e.g. Manville and White, 2003).

Acknowledgements. Our work at Coombs Hills and Allan Hills was supported by Antarctica New Zealand, the University of Otago, and the Fonds de recherche sur la nature et les technologies (Quebec, Canada). Bruce Houghton, Rick Sibson and Julie Rowland are acknowledged for helpful suggestions on an earlier draft, and Dougal Jerram for helpful comments on the submitted typescript.

\section{References}

Ballance, P. F. \& Watters, W. A. 1971. The Mawson Diamictite and the Carapace Sandstone, formations of the Ferrar Group at Allan Hills and Carapace Nunatak, Victoria Land, Antarctica. New Zealand Journal of Geology and Geophysics, 14, 512-527.

Boehm, A. \& Moore, J. C. 2002. Fluidized sandstone intrusions as an indicator of paleostress orientation, Santa Cruz, California. Geofluids, 2, 147-161.

Bradshaw, M. A. 1987. Additional field interpretation of the Jurassic sequence at Carapace Nunatak and Coombs Hills, south Victoria Land, Antarctica. New Zealand Journal of Geology and Geophysics, 30, 37-49.

Elliot, D. H. 2000. Stratigraphy of Jurassic pyroclastic rocks in the Transantarctic Mountains. Journal of African Earth Sciences, 31, 77-89.

Fleming, T. H., Heimann, A., Foland, K. A. \& Elliot, D. H. 1997. ${ }^{40} \mathrm{Ar} /{ }^{39} \mathrm{Ar}$ geochronology of Ferrar Dolerite sills from the Transantarctic Mountains, Antarctica: Implications for the age and origin of the Ferrar magmatic province. Geological Society of America Bulletin, 109, 533-546.

Grapes, R. H., Reid, D. L. \& Mcpherson, J. G. 1974. Shallow dolerite intrusion and phreatic eruption in the Allan Hills region, Antarctica. New Zealand Journal of Geology and Geophysics, 17, 563-577.

Gunn, B. M. \& Warren, G. 1962. Geology of Victoria Land between the Mawson and Murlock Glaciers, Antarctica. New Zealand Geological Society Bulletin, 71, $157 \mathrm{p}$.

Heiken, G., Wohletz, K. \& Eichelberger, J. 1998. Fracture fillings and intrusive pyroclasts, Inyo Domes, California. Journal of Geophysical Research, 93, 4335-4350.

Houghton, B. \& Wilson, C. J. N. 1989. A vesicularity index for pyroclastic deposits. Bulletin of Volcanology, 51, 451-462. 
Jolly, R. J. H. \& Lonergan, L. 2002. Mechanisms and controls on the formation of sand intrusions. Journal of the Geological Society, London, 159, 605-617.

Manville, V. M. \& White, J. D. L. 2003. Incipient granular mass flows at the base of sediment-laden floods, and the roles of flow competence and flow capacity in the deposition of stratified bouldery sands. Sedimentary Geology, 155, 157173.

Roche, O., Druitt, T. H. \& Cas, R. A. F. 2001. Experimental aqueous fluidization of ignimbrite. Journal of Volcanology and Geothermal Research, 112, 267-280.
Wilson, C. J. N. 1980. The role of fluidization in the emplacement of pyroclastic flows: an experimental approach. Journal of Volcanology and Geothermal Research, 8, 231-249.

White, J. D. L. \& McClintock, M. K. 2001. Immense vent complex marks flood-basalt eruption in a wet, failed rift: Coombs Hills, Antarctica. Geology, 29, 935-938.

\section{Figures}

Fig. 1. Distribution of the Mawson Formation (shaded) at Coombs Hills and Allan Hills, South Victoria Land, Antarctica. TAM stands for Transantarctic Mountains and WA is West Antarctica (inset map).

Fig. 2. Photo of a $\sim 12 \mathrm{~m}$-wide, type 1 clastic dyke (outlined) at Coombs Hills.

Fig. 3. Widths of all measured clastic dykes at Coombs and Allan Hills. The bell-shaped dashed curve is a normal distribution having the same mean and standard deviation as the natural logarithms of the data.

Fig. 4. Particle size distribution for the massive tuff centre of the widest clastic dyke (sample OU73269), compared with the subpopulation finer than 1.5 phi of a typical Mawson lapilli-tuff (OU73235). Equivalent diameters (diameters of circles having the same surface areas than the analysed particles) from image analysis of photomicrographs; volume fractions produced by grouping measurements into half-phi bins (over 200 particles measured per sample). Material not optically resolvable ( 20 modal $\%)$ excluded from the analysis.

Fig. 5. Schematic illustration of processes inferred for production of type 1 clastic dykes. Heat from magmatic intrusion fluidises host at contact, and buoyant hot fluids elutriate material upwards from intrusion and disperse it into the host. Below or along dipping intrusion fluids can't rise into host; buoyancy drives slurry laterally and upward; where it separates from heat source velocity is reduced and larger clasts lodge; finer material is strained through framework, accumulating in buoyancy-pressurized body. When host strength is exceeded, these fines inject upward as dyke. 


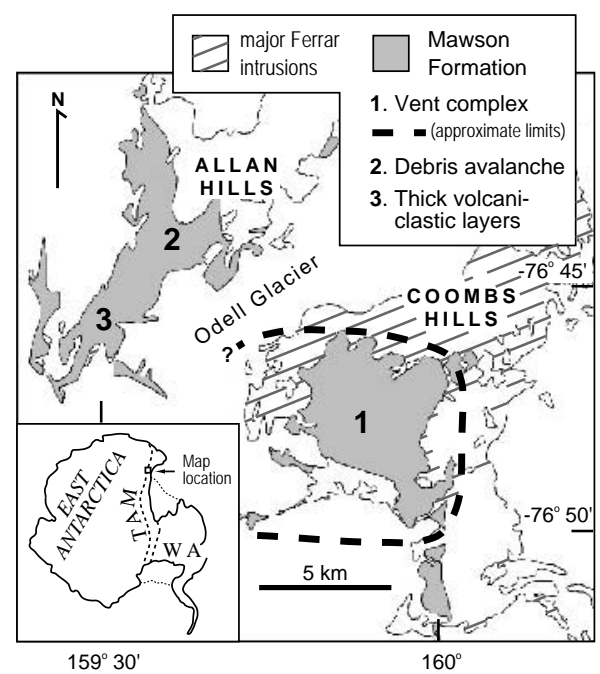

ROSS \& WHITE, CLASTIC DYKES, FIG. 1 


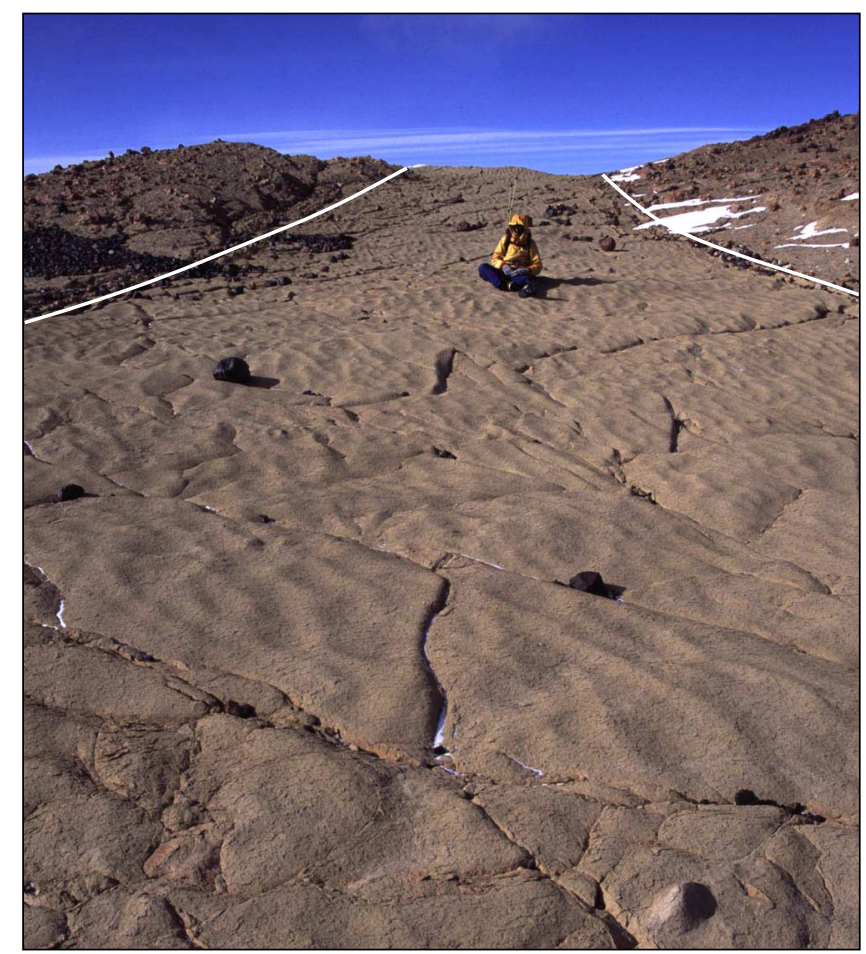

ROSS \& WHITE, CLASTIC DYKES, FIG. 2 


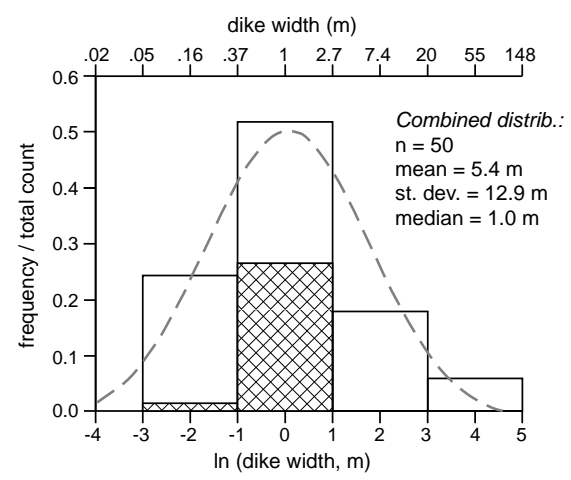

Allan Hills $(n=13$; all widths $<1.5 \mathrm{~m})$ $\square$ Coombs Hills $(n=37)$

ROSS \& WHITE, CLASTIC DYKES, FIG. 3 


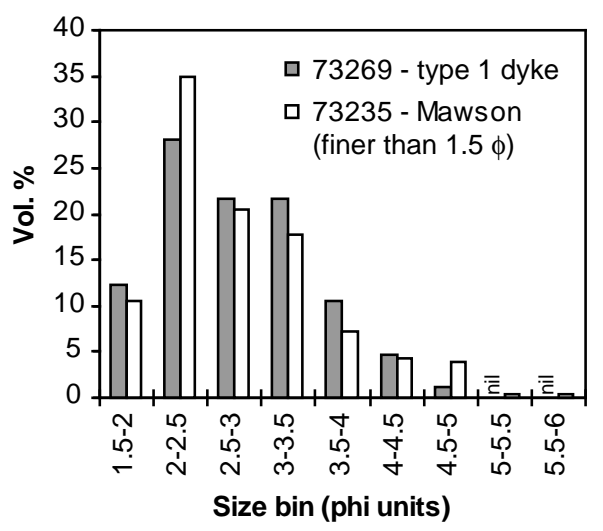

ROSS \& WHITE, CLASTIC DYKES, FIG. 4 


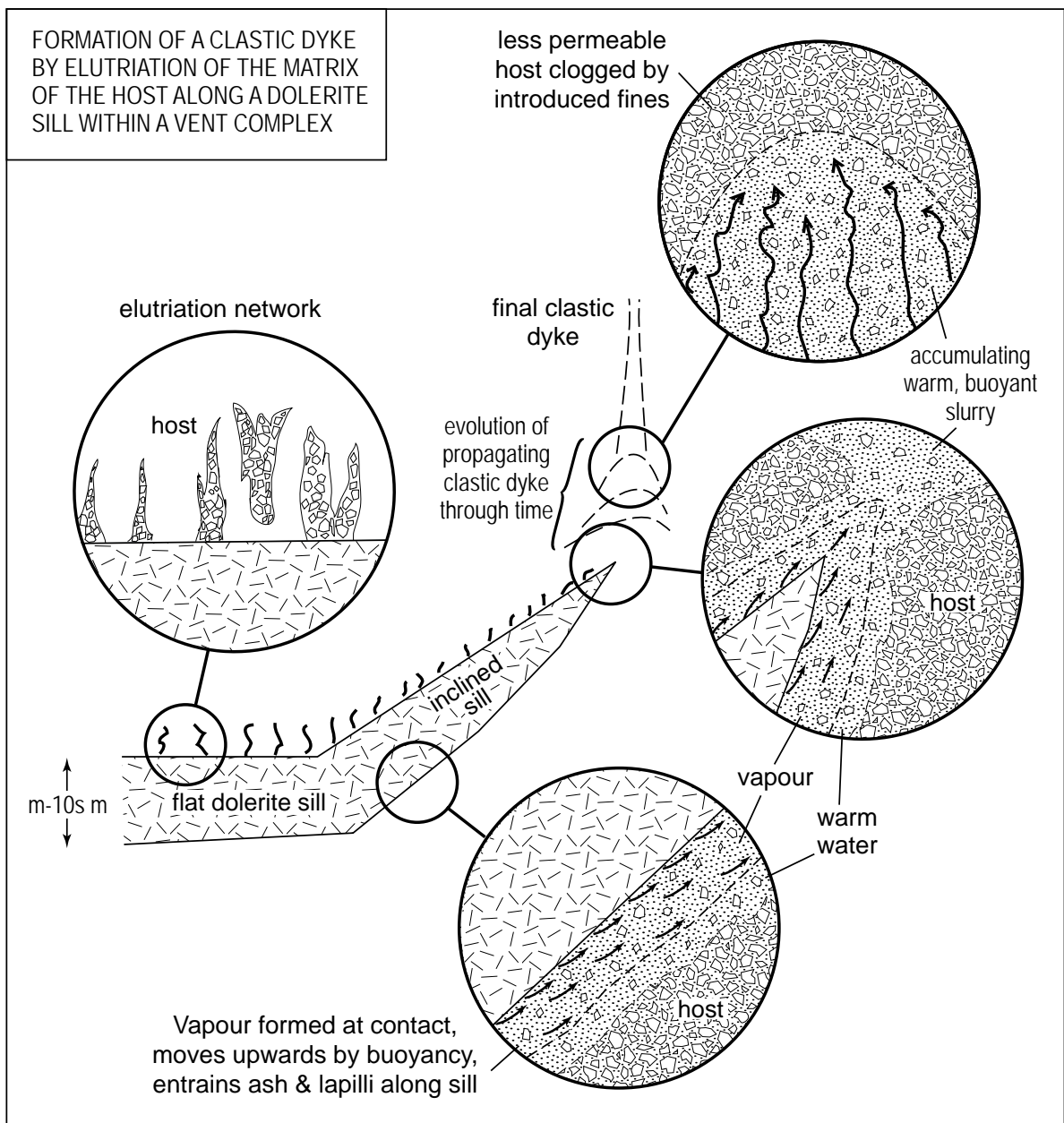

ROSS \& WHITE, CLASTIC DYKES, FIG. 5 